\title{
METODA PEMBENTUKAN LEMBARAN TIPIS AGAR-AGAR SECARA CEPAT SISTEM ROTARY DRUM GELATION
}

\section{Oleh :}

AMAL BAHARIAWAN *)

\begin{abstract}
Proses gelation dan pressing bertujuan untuk membentuk agar-agar menjadi lembaran tipis-tipis. Dua proses tersebut memerlukan waktu cukup lama, oleh karena itu proses tersebut dapat dipersingkat dengan cara pembentukan lemberan tipis menggunakan prinsip kerja rotary drum gelation. Drum dengan suhu permukaan yang dingin berputar menyentuh sedikit filtrat rumput laut sehingga filtrat tersebut akan membeku dan menempel pada permukaan drum dan selanjutnya dilakukan pelepasan dengan cara menyentukan pisau sayat pada permukaan drum sehingga lembaran tipis agar-agar terbentuk. Dengan cara, seperti ini maka pembentukan lembaran tipis hanya memerlukan satu tahapan dan waktu yang singkat. Tujuan yang ingin dicapai dalam penelitian ini adalah : menentukan kondisi operasional pengering semprot yang optimal untuk membuat tepung karaginan. Dari kegiatan penelitian ini dapat diambil kesimpulan sebagai berikut :

Dihasilkan sebuah alat pembentuk lembaran tipis agar-agar system drum gelation dengan sepesifikasi: (a) Dimensi alat (p,1,t) : $(75,60,90) \mathrm{cm}$,Dimensi Drum: $\varnothing=35 \mathrm{~cm}, \mathrm{p}=40 \mathrm{~cm}$, Bahan drum : plat SS $1 \mathrm{~mm}$, dan Penggerak Motor listrik $1 / 4$ HP, (b) Kondisi operasional pembentukan lembaran tipis agar-agar dengan menggunakan drum gelation sebagai berikut : Suhu drum masuk udara pengeringan : $0-10{ }^{\circ} \mathrm{C}$ dan Rpm drum : 0.5-2 rpm, (c) Hasil sementara pembentukan lembaran tipis agar-agar belum maksimal seperti lembaran yang dihasilkan teksturnya masih lemah
\end{abstract}

Kata kunci: agar-agar, gelation, rotary drum 


\section{PENDAHULUAN}

Rumput taut merupakan salah satu sumber devisa negara dan sumber pendapatan bagi masyarakat daerah pantai. Wilayah Indonesia yang sebagian besar (70\%) berupa taut merupakan negara yang kaya rumput taut. Memiliki usaha pembudidayaan rumput laut cukup menjanjikan karena kebutuhan ya setiap tahun semakin meningkat. Produksi rumput taut yang berlimpa ini setiap tahun diekspor dan sebagian digunakan untuk kebutuh $\mathrm{n}$ dalam negeri.

Selain digunakan langsung sebagai bahan makanan, rumput laut bisa diolah menjadi agaragar, karaginan, dan alginat. Namun sayang, Indonesia belum bisa mengolah rumput taut menjadi karaginan dan alginat sehingga kedua bahan ini selalu diimpor. Olahan rumput taut yang bisa diproduksi di Indonesia hanya agar-agar.

Pengolahan rumput laut menjadi agar-agar di lakukan dengan tahapan yang panjang yaitu: alkali treatment (4-6 jam), acid treatment (15 menit), extraction (4-8 jam), Filtering, Gelation (7 jam), Pressing, dan Drying.

Proses gelation dan pressing bertujuan untuk membentuk agar-agar menjadi lembaran tipistipis. Dua proses tersebut memerlukan waktu cukup lama, oleh karena itu proses tersebut dapat dipersingkat dengan cara pembentukan lemberan tipis menggunakan prinsip kerja rotary drum gelation

Drum dengan suhu permukaan yang dingin berputar menyentuh sedikit filtrat rumput laut sehingga filtrat tersebut akan membeku dan menempel pada permukaan drum dan selanjutnya dilakukan pelepasan dengan cara menyentukan pisau sayat pada permukaan drum sehingga lembaran tipis agar-agar terbentuk. Dengan cars, seperti ini maka pembentukan lembaran tipis hanya memerlukan satu tahapan dan waktu yang singkat. Dalam penelitian ini permasalahan yang perlu dicarikan pemecahannya adalah : Dimensi drum yang tepat, suhu permukaan drum, dan kecepatan putar drum sehingga dapat terbentuk lembaran agar-agar yang betul-betul tipis dengan waktu yang singkat.

\section{METODOLOGI}

\section{Tempat dan Waktu Penelitian}

Penelitian ini dilaksanakan di lingkungan Politeknik Negeri Jember seperti Bengkel Logam, dan Lab. Analisis. Penelitian ini dilakukan selama 6 bulan

\author{
Alat dan Bahan \\ Alat yang digunakan \\ a. Drum gelation \\ b. Dehumifikator \\ c. Ekstraktor \\ d. Centrifuse \\ e. Oven \\ f. Desikator \\ Bahan yang digunakan \\ a. Ekstrak rumput taut \\ b. Asam sulfat encer $10 \%$ \\ c. Asam cuka $0.5 \%$ \\ d. Kaporit $0.25 \%$
}

\section{Pelaksanaan Penelitian}

a. Menyiapkan ekstraksi rumput laut

1) Rumput taut yang telah melewati proses pembersihan awal dicuci lagi agar lebih bersih. Selanjutnya, rumput taut direndam dalam kaporit $0,25 \%$ selama 4 6 jam sambil diaduk sehingga diperoleh rumput taut yang berwarna putih dan bersih. Setelah itu, dicuci kembali untuk menghilangkan bau kaporit atau direndam air tawar selama 1-3 jam.

2) Selanjutnya, ditambahkan asam sulfat encer dan asam cuka, lalu diaduk selama 15 menit atau sampai lunak. Rumput taut dicuci kembali dengan air tawar bersih selama 15 menit, lalu ditiriskan.

3) Rumput laut basil rendaman asam sulfat dimasak dengan menambahkan 150 liter air dalam tangki pemasak. Pemanasan dilakukan sampai temperatur $90-100^{\circ} \mathrm{C}$ dan $\mathrm{pH}$ 5-6 (dalam suasana asam). Tingkat keasaman $(\mathrm{pH})$ diatur dengan cara menambahkan asam cuka 0,5\%. Selain untuk mempertahankan $\mathrm{pH}$, asam cuka juga berfungsi sebagai stabilizer sehingga diperoleh tekstur molekul yang konsisten. Pemasakan dilakukan selama 4-8 jam sambil diaduk hingga merata. Dalam satu hari, proses pemasakan bisa juga dilakukan dua kali (2 $\mathrm{x} 4$ jam). Pemasakan dilakukan sampai mendidih, rumput laut hancur dan larut menjadi bubur encer.

4) Bubur rumput laut yang encer disaring hingga larutan dan residu terpisah. 


\section{b. Perancangan Alat Rotary Drum Gelation}

Prinsip kerja alat adalah menyentuhkan permukaan drum dingin yang berputar pada filtrat rumput laut sehingga filtrat akan membeku dan membentuk lapisan tipis pada permukaan drum dan selanjutnya dilepaskan dengan pisau sayat. Untuk lebih jelasnya dapat dilihat pada gambar lampiran 1 .

\section{Metode Percobaan}

Percobaan dilakukan dengan rancangan acak Iengkap faktorial dengan faktor utama kecepatan putar drum (p1) : 1/2 rpm, (p2) $1 \mathrm{rpm}$ dan (p3) 2 rpm dan faktor kedua adalah besar suhu permukaan drum (s1) $0^{\circ} \mathrm{C}$, (s2) $5^{\circ} \mathrm{C}$ dan (s3) $10^{\circ} \mathrm{C}$. Parameter pengamatan meliputi : ketebalan lembaran, keutuhan lembaran, keseragaman tebal lembaran.

\section{HASIL DAN PEMBAHASAN}

Kegiatan penelitian ini diawali dari pemikiran bahwa untuk memperoleh lembaran tipis agar-agar dari ekstrak rumput laut yang selama ini dilakukan dengan dua proses memerlukan waktu cukup lama, oleh karena itu proses tersebut dapat dipersingkat dengan cara pembentukan lembaran tipis menggunakan prinsip kerja rotary drum gelation. Drum dengan suhu permukaan yang dingin berputar menyentuh sedikit filtrat rumput laut sehingga filtrat tersebut akan membeku dan menempel pada permukaan drum dan selanjutnya dilakukan pelepasan dengan cara menyentukan pisau sayat pada permukaan drum sehingga lembaran tipis agar-agar terbentuk. Dengan cara, seperti ini maka pembentukan lembaran tipis hanya memerlukan satu tahapan dan waktu yang singkat.

Dari hasil penelitian maka dihasilkan suatu alat drum gelation yang mempunyai sepsifikasi alat:

Dimensi alat $(\mathrm{p}, 1, \mathrm{t}) \quad:(75,60,90) \mathrm{cm}$

Dimensi Drum $: \varnothing=35 \mathrm{~cm}, \mathrm{p}=40 \mathrm{~cm}$

RPM Drum : : $1 / 2-2 \mathrm{rpm}$

Bahan drum : plat SS $1 \mathrm{~mm}$

Penggerak : : Motor listrik $1 / 4 \mathrm{HP}$
Pengkondisian suhu dilakukan secara manual yaitu dengan cara memberikan udara dingin pada drum melalui pipa as berlubang.

Pelaksanaan kegiatan dilakukan dengan cara menempatkan cairan ekstrak rumput laut yang masih panas kedalam wadah dibawah drum sampai

permukaan drum tenggelam sekitar $1 \mathrm{~cm}$. udara dingin dialirkan kedalam drum melalui pipa as berlubang sampai suhu drum sesuai dengan yang diinginkan, selanjutnya drum diputar dengan putaran $1 / 2 \mathrm{rpm}$. Dengan kondisi demikian maka cairan ekstrak agar-agar akan menempel pada permukaan drum yang bersuhu rendah tersebut dan selanjutnya dilakukan penyayatan lapisan tersebut sehingga akan terbentuk lembaran tipis agar. Dari hasil penelitian yang berlanjut lembaran tipis yang terbentuk masih belum optimal seperti lembaran yang dihasilkan teksturnya masih lemah sehingga mudah rusak. Untuk lebih sempurnanya hasil penelitian ini maka perlu dilakukan penelitian lebih lanjut dengan penambahan perlakuan seperti penghembusan udara sehingga lembaran tipis yang terjadi mempunyai tekstur yang lebih kuat.

\section{KESIMPULAN DAN SARAN}

\section{Kesimpulan}

Dari kegiatan penelitian ini dapat diambil kesimpulan sebagai berikut :

1) Dihasilkan sebuah alat pembentuk lembaran tipis agar-agar system drum gelation dengan sepesifikasi :

Dimensi alat $(\mathrm{p}, 1, \mathrm{t}) \quad:(75,60,90) \mathrm{cm}$

Dimensi Drum $: \varnothing=35 \mathrm{~cm}, \mathrm{p}=40 \mathrm{~cm}$

Bahan drum : plat SS $1 \mathrm{~mm}$

Penggerak : Motor listrik $1 / 4$ HP

2) Kondisi operasional pembentukan lembaran tipis agar-agar dengan menggunakan drum gelation sebagai berikut :

Suhu drum masuk udara pengeringan : 0-10 ${ }^{\circ} \mathrm{CRpm}$ drum : 0.5-2 rpm

3) Hasil sementara pembentukan lembaran tipis agaragar belum maksimal seperti lembaran yang dihasilkan teksturnya masih lemah.

\section{Saran}

Untuk lebih menyempurnakan hasil Lembaran tipis agar-agar yang diperoleh perlu penelitian lebih lanjut dengan menambahkan penghembusan udara sehingga lembaran yang dihasilkan teksturnya lebih kuat. 
Amal B, Metoda Pembentukan Lembaran Tipis Agar-Agar Secara Cepat Sistem Rotary Drum Gelation

\section{DAFTAR PUSTAKA}

Crowe, C.T., 1980, Modeling Spary Air Contact in Spray Drying System, Advance in Drying Vol 1, p. : (64-96), Mujumdar, A.S. editor, Hemisphere Publ. Co., Washington, D.C.

Departemen Kelautan dan Perikanan RI, 2003, Pesona Rumpu Laut sebagai Sumber Devisa, Dep. Kelautan dan Perikanan.

Masters, K., 1980, Spray Drying, Advance in Drying Vol 1, p. : (265-298), Mujumdar, A.S. editor,
Hemisphere Publ. Co., Washington, D.C.

Istini, S., A. Zatnika dan Suhaimi, 1985, Manfaat dan Pengolahan Rumput Laut, FAO, Corporate Document Repository.

Lazar, M.E. , A.H. Brown, G.S. Smitf, F.F. Wong and F.E. Lindquist, 1956, Experimental Production of Tomato powder by spray drying, Food Technology, 10, 29

Welti, J.S. and B. Lafuente, 1983, Spray Drying of Communited Orange Product I : influence of air Temperatur and Feed Rate on Product Quality, in FSTA 16, 1984, 8

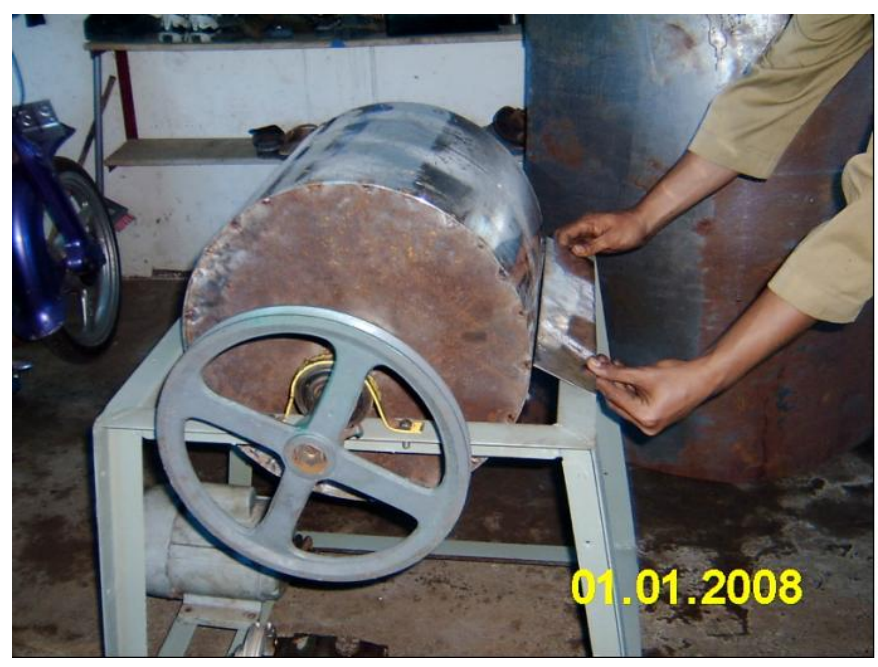

